\title{
A simple RT-PCR-based strategy for screening connexin identity
}

\section{Urban ${ }^{1}$ \\ R. Rozental ${ }^{1,2,4}$ and D.C. Spray $1,3,4$}

\author{
Departments of ${ }^{1} \mathrm{~N}$ euroscience, ${ }^{2} \mathrm{Anesthesiology}$ and ${ }^{3} \mathrm{M}$ edicine, \\ Albert Einstein College of Medicine, New York, NY, USA \\ ${ }^{4}$ Departamento de Medicina Interna and Instituto de Patologia Tropical e Saúde \\ Pública, Universidade Federal de Goiás, Goiânia, GO , Brasil
}

\section{Correspondence \\ R. Rozental \\ Department of Neuroscience Albert Einstein College of Medicine \\ Kennedy Center Room \# 724 \\ 1300 Morris Park Avenue \\ New York 10461, NY \\ USA \\ Fax: + 1-718-430-8682 \\ E-mail: rozental@ aecom.yu.edu \\ Research supported by the $\mathrm{N}$ ational Institutes of Health.}

Received September 18, 1998 Accepted April 5, 1999

\section{Abstract}

Vertebrate gap junctions are aggregates of transmembrane channels which are composed of connexin $(\mathrm{Cx})$ proteins encoded by at least fourteen distinct genes in mammals. Since the same Cx type can be expressed in different tissues and more than one Cx type can be expressed by the same cell, the thorough identification of which connexin is in which cell type and how connexin expression changes after experimental manipulation has become quite laborious. Here we describe an efficient, rapid and simple method by which connexin type(s) can be identified in mammalian tissue and cultured cells using endonuclease cleavage of RT-PCR products generated from "multi primers" (sense primer, degenerate oligonucleotide corresponding to a region of the first extracellular domain; antisense primer, degenerate oligonucleotide complementary to the second extracellular domain) that amplify the cytoplasmic loop regions of all known connexins except Cx36. In addition, we provide sequence information on RTPCR primers used in our laboratory to screen individual connexins and predictions of extension of the "multi primer" method to several human connexins.

\section{Introduction}

Gap junction channels are found in most tissues where they provide conduits for diffusion of ions and small molecules between neighboring cells. Cloning studies have thus far revealed fourteen distinct connexin $(\mathrm{Cx})$ cDNA sequences encoded by different genes in rodent tissues with highly homologous isoforms in other mammals. In mammals, group I (ß) connexins include Cx26, Cx30, $\mathrm{Cx} 30.3, \mathrm{Cx} 31, \mathrm{Cx} 31.1$ and $\mathrm{Cx} 32$, and group II $(\alpha)$ connexins include $\mathrm{Cx} 33, \mathrm{Cx} 37, \mathrm{Cx} 40$,

\section{Key words}

- Gap junctions

- Intercellular communication

- cDNA sequences

- Universal primers

- Multi primers
$\mathrm{Cx} 43, \mathrm{Cx} 45, \mathrm{Cx} 46$ and $\mathrm{Cx} 50$ (1). In addition, a new connexin type (named $\mathrm{Cx} 36$ ) has been identified in the mammalian brain and assigned to a new group of connexins termed group III $(\gamma)(2,3)$.

Methods that have become standard for establishing identities of connexins within specific tissues include Northern blot and Western blotting and immunocytochemical assays. However, these methods require relatively high amounts of RNA and protein, and detection of protein requires connexinspecific antisera (few of which are commer- 
cially available). To circumvent these drawbacks, we have developed a rapid method for screening connexin identity using RTPCR techniques. Because nucleotide sequences of connexin cDNAs are highly conserved in both intramembrane and extracellular domains, a pair of degenerate oligonucleotide primers were previously designed to amplify the cytoplasmic loop regions of all known connexins (4). Here, we have utilized this pair of "multi primers" to amplify connexin DNA sequences starting from total RNA and identified individual connexin species through the use of specific endonucleases; amplification of the cytoplasmic loop regions results in major bands that distinguish group I from group II connexins. We show that group I connexins display sizes on gels of 350-390 bp, while group II connexin sequences amplified by these primers are $420-520 \mathrm{bp}$. We also show that certain connexins are not readily identified by this technique and propose connexinspecific RT-PCR primers to overcome this limitation.

In the present study we amplified cloned cDNAs representing connexins from groups I and II (Figures 1 and 2) and identified connexins generated by reverse-transcribed RNA samples from a neural cell line (Figure 3 ); the identity of the connexin was confirmed by sequencing. Finally, we demonstrate the applicability of our method by detecting the connexins expressed in the liver (i.e., Cx26, Cx32 and Cx43; Figure 4 and Table 1). We provide a detailed "bench-top" protocol and a succinct description of our methodology, discuss its potential applica-
Figure 1 - Detection of connexins belonging to groups I $(\mathrm{rC} \times 26$, $\mathrm{rCx} 32)$ and II (rCx43, $\mathrm{mC} \times 45)$ using "multi primers" with connexin-cloned CDNA. PCR products corresponding to $382 \mathrm{bp}$ for Cx26, 381 bp for Cx32, 431 bp for $\mathrm{C} \times 43,518 \mathrm{bp}$ for $\mathrm{C} \times 45$. Molecular markers are indicated on the left (M). r, Rat; $m$, mouse.
Figure 2 - Digestion of PCR products of clonned connexin cDNAs by specific endonucleases. The endonucleases used were $\mathrm{Msel}$ ( $\mathrm{rC} \times 26), \mathrm{EcoNI}(\mathrm{rC} \times 32), \mathrm{Msel}$ ( $\mathrm{rC} \times 33)$, Fspl $(\mathrm{rC} \times 40)$, Hincll ( $\mathrm{rC} \times 43)$, and EcoRI (mCx45). Molecular markers are indicated on the left (M). $r$, Rat; $m$, mouse.
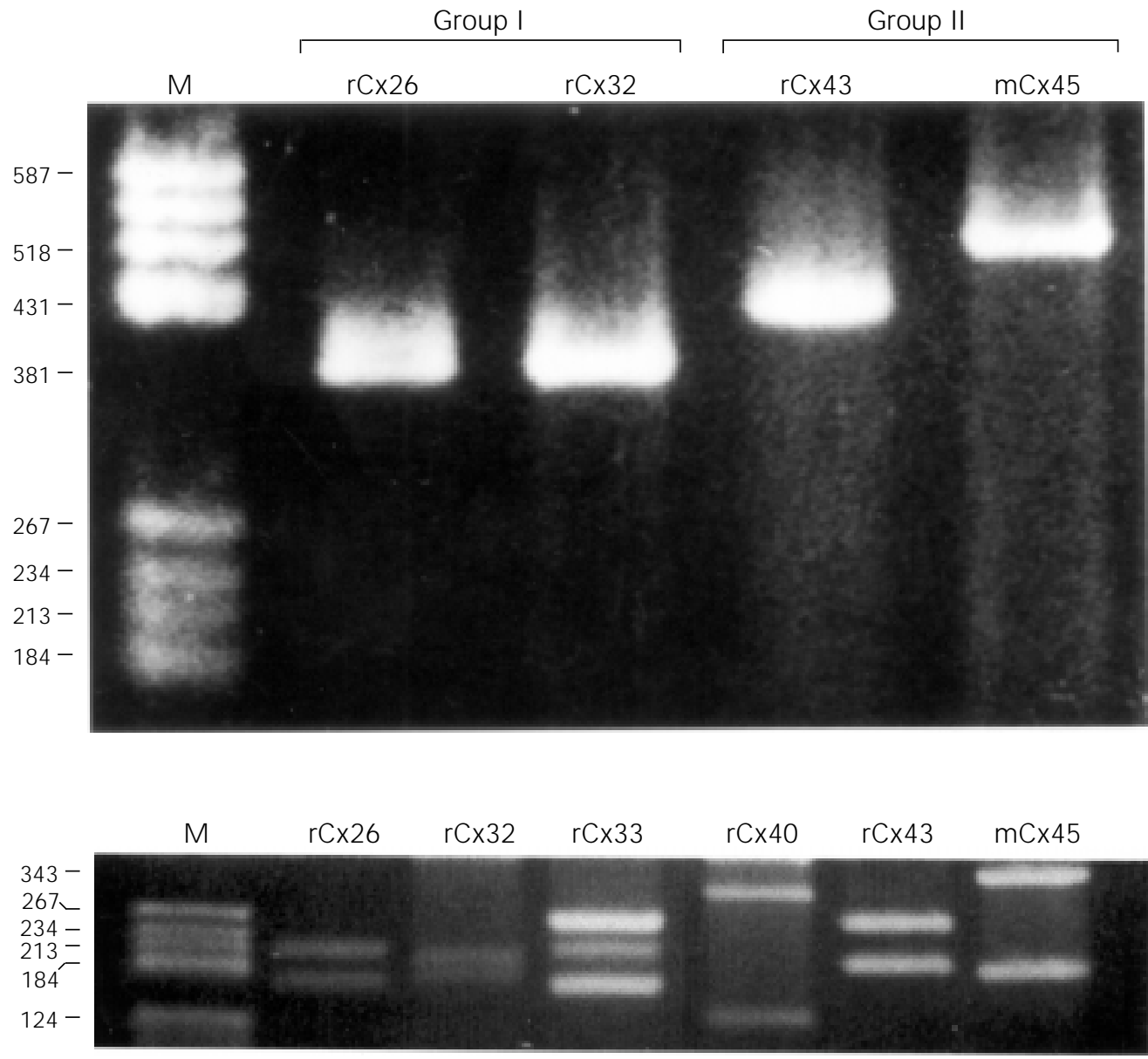


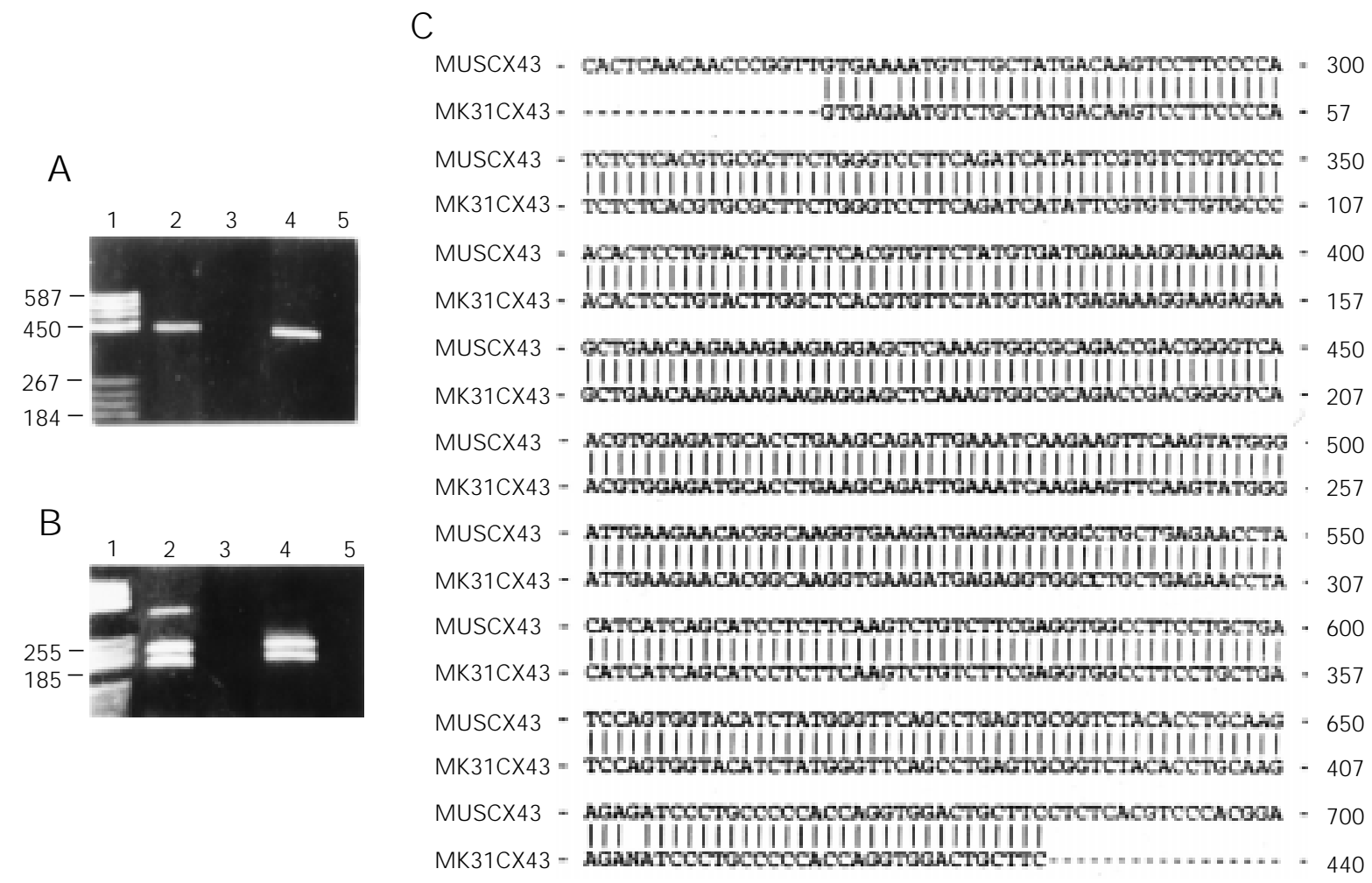

Figure 3 - Connexin detection in a neural cell line (MK31 cell line). Bench-top protocol of our methodology and potential applications. A, Screening connexin identity in a cell line using RT-PCR assays. First generation of PCR products indicates that the amplified DNA sequences belong to group II $(A 2,4)$. B2, Second generation of PCR products indicates the expression of Cx43 in these cells. Lane 4 is the PCR product of $\mathrm{C} \times 43$ from rat heart and lane 5 is its corresponding negative control. B, Lanes 2,4 show the presence of restriction products of $\mathrm{Cx} 43$ after Hincll was used. Lane 3 is a negative control for the cells. The negative controls were run in PCR without reverse transcriptase to verify that genomic DNA was not present (lanes 3,5). C, Sequencing the RT-PCR products revealed the presence of Cx43 (99.7\% identical) in these cells. Terminology: Mouse heart Cx43 sequence (MUSCX43) and sequence found in the neural cell line (M K31CX43). Molecular markers (A1, B1).

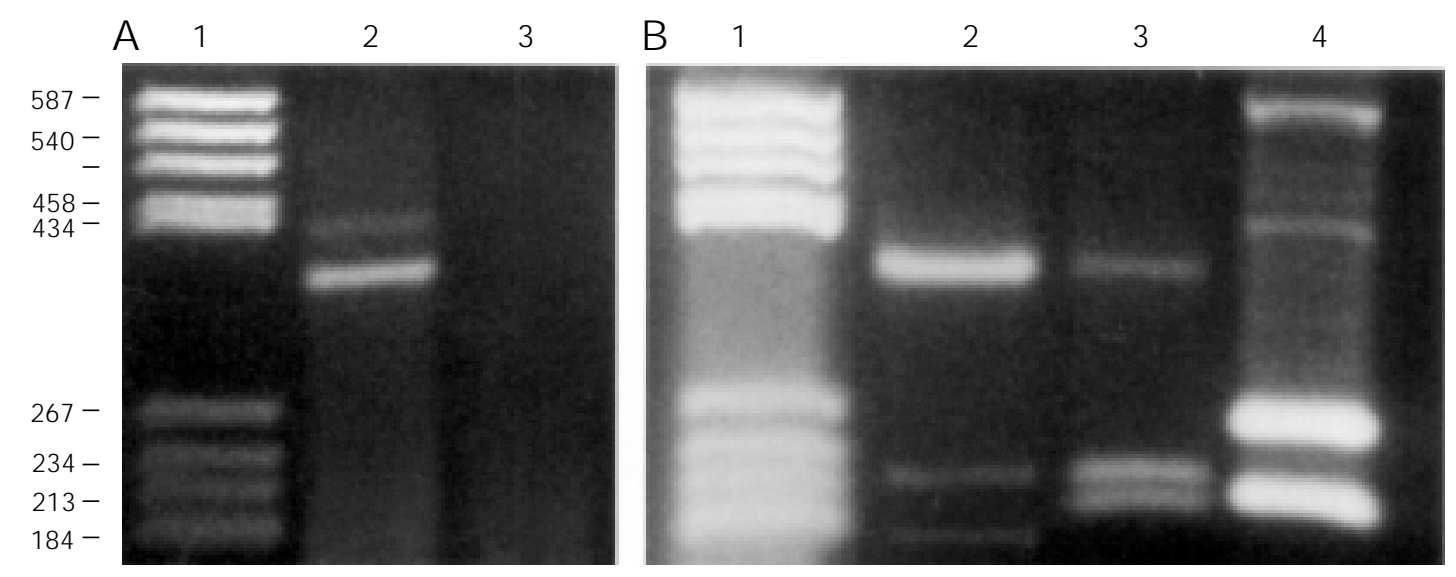

Figure 4 - Determination of the connexin types expressed in rat liver. A, First generation of PCR products indicates that the amplified DNA sequences belong to groups I and II (lane 2), as expected, and its corresponding negative control (lane 3). Molecular markers (lane 1). B, Second generation of PCR products. For this figure, first round PCR bands were isolated from the gel and PCR products belonging to Cx26 (lane 2), Cx32 (lane 3) and Cx43 (lane 4) were identified, as expected. Molecular markers (lane 1). The endonucleases used were Msel (Cx26; lane 2), EcoNI (Cx32; lane 3) and Hincll (Cx43; lane 4), respectively. 
tions and limitations and provide advice on avoiding potential pitfalls. In addition, we also provide GenBank access numbers for connexin types expressed in rodents and humans (Tables 1 and 2), a list of specific restriction enzymes to be used and sequences for connexin-specific primers (Table 3 ) routinely used in our laboratory. Thus, this communication provides a starting point for those new to the gap junction field and should also serve as a useful reference for more experienced researchers.

\section{Material and Methods}

\section{Preparation and treatment of RNA}

Total RNA was isolated from cultured cells or tissues by a procedure based on that of Chomczynski and Sacchi (5), quantitated by absorbance measurements at $260 \mathrm{~nm}$ and $280 \mathrm{~nm}$ (Hitachi U-1100) with 1 OD unit considered equal to $40 \mu \mathrm{g} / \mathrm{ml}$. Ten $U$ of DNase I (Boehringer Mannheim, Indianapolis, IN, USA) was added to each $5 \mu \mathrm{g}$ of RNA and incubated at $25^{\circ} \mathrm{C}$ for $15 \mathrm{~min}$ to digest residual genomic DNA. DNase was heatinactivated at $65^{\circ} \mathrm{C}$ for $15 \mathrm{~min}$ before the RTPCR analyses.

\section{RT-PCR analyses}

First strand cDNA was synthesized from total RNA templates using random primers and the superscript preamplification system (Gibco BRL-Life Technologies, Inc., Grand Island, NY, USA) (6). One to two micrograms of total RNA was brought to $11 \mu \mathrm{l}$ in diethyl pyrocarbonate (DEPC)-treated water and combined with $1 \mu \mathrm{l}$ random hexamers $(50 \mathrm{ng} / \mu \mathrm{l})$. The mixture was heated at $70^{\circ} \mathrm{C}$ for $10 \mathrm{~min}$ and then incubated on ice. The remaining components for reverse transcription were then added and incubated for 10 min as follows: $2 \mu 1$ of $10 \mathrm{x}$ synthesis buffer, $2 \mu 10.1$ M DTT, $2 \mu 125 \mathrm{mM} \mathrm{MgCl}_{2}, 1 \mu 110$ $\mathrm{mM}$ dNTP mix and $1 \mu \mathrm{l}$ (200 units) super- script reverse transcriptase. The reaction mix was left at room temperature (RT) for 10 min, incubated at $42^{\circ} \mathrm{C}$ for $50 \mathrm{~min}$ and the reaction terminated by incubating at $70^{\circ} \mathrm{C}$ for $15 \mathrm{~min}$.

Degenerate oligonucleotides corresponding to conserved regions of the first and second extracellular connexin domains were synthesized on an ABI model 391 Sequencer (Applied Biosystems, Foster City, CA, USA). The sequences of the 24-mer sense and 21mer antisense "multi primers" (4) are given below (using IUB group codes):

A) Sense 5' GGC TGT RAV AAY GTC TGC TAY GAC 3'

B) Antisense 5' TGG GVC KGG AVA BGA AGC AGT 3'

PCR reactions contained (in a final volume of $50 \mu \mathrm{l}): 5 \mu \mathrm{l}$ of RT reaction $(0.5-1 \mu \mathrm{g}$ of first strand cDNA), $1 \mu \mathrm{M}$ of sense and antisense primers, $5 \mu 1$ of 10x PCR buffer (100 $\mathrm{mM}$ Tris-HCl; $500 \mathrm{mM} \mathrm{KCl}, \mathrm{pH} \mathrm{8.3),} 0.2$ $\mathrm{mM}$ dNTP, $3 \mathrm{mM} \mathrm{MgCl}_{2}$ and $2.5 \mathrm{U}$ Taq polymerase (Gibco BRL-Life Technologies, Inc.). Thirty cycles were performed on the samples using a PTC-100 Thermocycler (M.J. Research Inc., Watertown, MA, USA) as follows: 1) denaturation at $94^{\circ} \mathrm{C}$ for $30 \mathrm{~s} ; 2$ ) annealing at $55^{\circ} \mathrm{C}$ for $30 \mathrm{~s} ; 3$ ) extension at $72^{\circ} \mathrm{C}$ for $30 \mathrm{~s}$. This was followed by a final extension cycle at $72^{\circ} \mathrm{C}$ for $8 \mathrm{~min}$ and a soak cycle at $4^{\circ} \mathrm{C}$. Reaction products were analyzed by electrophoresis on $2 \%$ agarose gels in order to detect contaminants. The corresponding bands were isolated from gels and purified (Qiagen Inc., Valencia, CA, USA). The DNA was reamplified, and restriction digestion analysis with specific enzymes (New England Biolabs Inc., Beverly, MA, USA) was performed to identify the connexins expressed in the rat liver and in a mouse neural cell line (MK31 cell line; 7,8).

Amplicon sizes were determined in agarose DNA gels following electrophoresis with markers corresponding to 8 to 587 bp. 


\section{DNA sequencing and analysis}

RT-PCR products detected in hippocampal cells were sequenced and compared to murine cytoplasmic loop connexin sequences available at GenBank (Figure 3C).

\section{Results and Discussion}

This report describes an improved technique for the screening of tissue- or cellspecific RNA samples for the presence of mRNAs encoding members of the connexin multigene family. Previous studies have utilized RT-PCR techniques to detect connexin expression in different preparations (9-17). However, our methodology is novel in the ability to detect all known connexins belonging to groups I and II through the use of "multi primers" with only a single PCR reaction followed by specific restriction digestions. The previous methods required the use of specific conditions and specific primers for each connexin type and the reported methods lacked detailed experimental protocols. In addition, our study presents theoretical cleavage patterns of connexin PCR products specific for each connexin type as well as the GenBank access numbers for each connexin.

In contrast to previous publications, we have used the terminology "multi primers" instead of "universal primers", due to the fact that these degenerate oligonucleotides do not amplify the cytoplasmic loop regions of Cx36 (group III) and do not detect Cx37, $\mathrm{Cx} 40$ and $\mathrm{Cx} 45$ in a background where $\mathrm{Cx} 43$ is present.

The protocol we developed evolved from the use of degenerate oligonucleotides for PCR amplification of connexins reported by Haefliger et al. (4). Optimization of our preparation was achieved by reducing the duration of denaturation at $94^{\circ} \mathrm{C}$ from $1 \mathrm{~min}$ to $30 \mathrm{~s}$, annealing at $55^{\circ} \mathrm{C}$ and extension at $72^{\circ} \mathrm{C}$ for $30 \mathrm{~s}$ and the final extension to $8 \mathrm{~min}$. By reducing the duration of the cycles used by
Haefliger et al. (4) by $50 \%$ (from $1 \mathrm{~min}$ to 30 s) and by increasing the concentration of $\mathrm{MgCl}_{2}$ from 1.5 to $3 \mathrm{mM}$ we have detected 8 connexin types in various cell and tissue preparations (Figures 1, 2, 3A,B, 4; Table 1).

"Multi primers" amplified sequences conserved among connexins, resulting in major bands that distinguished group I (350-390 bp) from group II (420-520 bp) connexins; these results are illustrated in Figure 1 for the group I connexins with $\mathrm{C} \times 26$ and $\mathrm{C} \times 32$ and for the group II connexins $\mathrm{Cx} 43$ and $\mathrm{Cx} 45$. Unique restriction sites within the amplicons generated by "multi primers" for each rodent and human connexin for which sequence information exists were deduced from the program PCGene (IntelliGenetics, Inc., Campbell, CA, USA). These predicted fragment sizes for rodent and human connexins are presented in Tables 1 and 2. Our predictions for the sizes of PCR product fragments after endonuclease treatment were confirmed using amplicons obtained from PCR with "multi primers" using cloned cDNAs encoding Cx26, Cx32, Cx33, Cx40, Cx43 and Cx45 (Figure 2); so far the only anomaly has been the presence of a canonical site for EcoNI in rat Cx32 DNA leading to an unexpected cleavage product of $213 \mathrm{bp}$ (see Figure $2, \mathrm{rCx} 32$ ).

In various cell lines and tissues, we have used this technique to detect $\mathrm{Cx} 26, \mathrm{Cx} 32$, Cx33, Cx36, Cx37, Cx40, Cx43, Cx46 and Cx50. Use of the method for detection of $\mathrm{Cx} 43$ in a neural cell line (MK31 cell line) is illustrated in Figure 3. We first assigned products as corresponding to group I or group II connexins on the basis of length (Figure 3A), and verified identity of the amplicons using digestion with endonucleases for unique sites (Figure 3B). Subcloning of these products and subsequent sequencing provided additional confirmation of the identity of the specific connexins expressed (Figure 3C). Figure 4 illustrates the applicability of this method to detect typical connexins expressed in the liver, i.e., Cx26 (Figure 4B2), Cx32 (Figure 4B3) 
Table 1 - PCR products obtained from the 14 connexins expressed in rodents. Detection of connexin type identity from PCR products. PCR products of CDNA of Cx26, Cx30.3, Cx31, Cx31.1, Cx32, Cx33, Cx37, Cx40, Cx43, Cx45, Cx46 and Cx50.

$r$, Rat; $m$, mouse. Tissues with high expression, references for molecular cloning and GenBank database accession numbers are listed below. *A cleavage product of 213 bp, corresponding to a canonical site for EcoNI, is routinely found in rat liver. N.A., Not available; N.T., not tested.

Connexin (Cx) GenBank access \# References Restriction enzymes Products (bp)

\begin{tabular}{|c|c|c|c|c|}
\hline $\mathrm{rC} \times 26$ & X51615 (liver) & 18 & Msel & 169,213 \\
\hline $\mathrm{mCx} 26$ & M81445 (liver) & 19 & Msel & 170,213 \\
\hline rCx30 & N.A. & - & - & - \\
\hline $\mathrm{mCx} 30$ & Z70023 (skin) & 20 & Fspl & 177, 204 \\
\hline $\mathrm{rC} \times 30.3$ & X76168 (skin) & 21 & NrUI & 118,248 \\
\hline $\mathrm{mC} \times 30.3$ & M91443 (skin) & 22 & Sapl & 115,252 \\
\hline rCx31 & M59936 (skin) & 23 & Avall & 158,211 \\
\hline $\mathrm{mC} \times 31$ & X63099 (skin) & 24 & Avall & 159,211 \\
\hline rCx31.1 & M 76533 (skin) & 4 & Xhol & 124,236 \\
\hline $\mathrm{mC} \times 31.1$ & M91442 (skin) & 22 & Xhol & 124,237 \\
\hline $\mathrm{rC} \times 32$ & X04070 (liver) & 25 & EcoNI & $178,201 *$ \\
\hline $\mathrm{mC} \times 32$ & M81447 (liver) & 19 & EcoNI & $177,201^{*}$ \\
\hline rCx33 & M 76534 (testis) & 4 & Msel & 170,265 \\
\hline mCx33 & N.A. & - & - & - \\
\hline rCx36 & Y16898 (retina) & 3 & N.T. & N.T. \\
\hline $\mathrm{mCx} 36$ & AF016190 (brain) & 2 & N.T. & N.T. \\
\hline rCx37 & M76532 (lung) & 4 & BgllI & 204,229 \\
\hline $\mathrm{mCx} 37$ & X57971 (lung) & 26 & Bglll & 203,230 \\
\hline rCx40 & M76535 (lung) & 4 & Fspl & 124,301 \\
\hline $\mathrm{mCx} 40$ & X61675 (lung) & 27 & Fspl & 124,303 \\
\hline rCx43 & X06656 (heart) & 28 & Hincll & 185,255 \\
\hline $\mathrm{mCx} 43$ & X61576 (heart) & 29 & Hincll & 186,247 \\
\hline rCx45 & N.A. & - & - & - \\
\hline $\mathrm{mCx} 45$ & X63100 (heart) & 24 & EcoRI & 177,343 \\
\hline rCx46 & X57970 (lens) & 30 & Eagl & 185,246 \\
\hline $\mathrm{mC} \times 46$ & N.A. & - & - & - \\
\hline rCx50 & N.A. & - & - & - \\
\hline mCx50 & M91243 (lens) & 31 & EcoNI & 117,324 \\
\hline
\end{tabular}

Table 2 - Predicted unique cleavage sites for human gap junction proteins deduced from cDNA sequences.

References for GenBank database accession numbers, molecular cloning, restriction enzymes and predicted cleavage patterns.

Connexin (Cx) GenBank access \# References Restriction enzymes Products (bp)

\begin{tabular}{llllr}
\hline CX26 & M86849 & 32 & Msel & 170,213 \\
CX32 & X04325 & 33 & Ddel & 100,279 \\
CX37 & M96789 & 34 & BgllI & 203,229 \\
CX40 & U03486 & 35 & Dralll & 119,307 \\
CX43 & M65188 & 36 & ScrFI & 99,333 \\
CX45 & U03493 & 35 & Ddel & 197,304
\end{tabular}

and Cx43 (Figure 4B4) (Table 1).

\section{Precautions}

Problems with RT-PCR sensitivity generally are associated with duration and temperature of incubation, numbers of cycles and reagents (in particular, $\mathrm{Mg}^{2+}$ ). Incubation times should be kept as short as possible in order to optimize the protocol and minimize the occurrence of non-specific amplification. Since one of the key variables in this protocol is the concentration of $\mathrm{Mg}^{2+}$ and $\mathrm{Mg}^{2+}$ concentration requirements can vary dramatically depending on the sample to be studied, we recommend that a concentration curve for $\mathrm{Mg}^{2+}$ be established before completely implementing this protocol in order to avoid nonspecific priming and suboptimal enzymatic activity. For preliminary characterization of the connexins expressed in a specific tissue, we suggest the use of the "Q-solution" (Qiagen Inc.) which acts similarly to DMSO by modifying the melting behavior of DNA. More importantly, it has been shown that the concentration of $\mathrm{Mg}^{2+}$ does not need to be previously adjusted, providing an efficient amplification at a uniform concentration.

Although this method is now optimized to the point where it is reliable in discriminating many different connexin types, we have thus far been unable to detect $\mathrm{Cx} 37$, $\mathrm{Cx} 40$ and $\mathrm{Cx} 45$ in tissues where $\mathrm{Cx} 43$ is coexpressed. Nevertheless, one cannot rely only on the electrophoretic separation for identification of amplicons in agarose DNA gels. To substantiate the identity of the connexins, we strongly recommend one of the following strategies: i) all amplicons must be sequenced (as illustrated in Figure 3C), or ii) use of specific primers (Table 3 ), as still required for $\mathrm{Cx} 37, \mathrm{Cx} 40, \mathrm{Cx} 45$ and $\mathrm{Cx} 36$ (see 13,17). In our laboratory, immunocytochemical and functional electrophysiological assays have been routinely carried out in parallel to further substantiate the results obtained using the RT-PCR strategy. 
Table 3 - Connexin-specific primers routinely used to verify the expression of connexins expressed in mice (*except Cx33 and Cx46).

*Mouse Cx33 and Cx46 sequences are not yet available (see Table 1); Cx33- and Cx46-specific primers are listed for rat sequences (e.g., rCx33 and rCx46).

\begin{tabular}{|c|c|c|}
\hline$C x$ & Sequence $\left(5^{\prime}-3^{\prime}\right)$ (sense) & Sequence $\left(5^{\prime}-3^{\prime}\right)$ (antisense) \\
\hline$C \times 26$ & AGATGGAGGGAGAGGATGAG & TCAGAGGAAGAGAAACAATGTG (312bp) \\
\hline $\mathrm{C} \times 30$ & GGCTTGGTTTTCAGAGATAG & GAGTTGTGTTACCTGCTGC (369bp) \\
\hline Cx30.3 & CACCGTATGTGATCTCCAAAG & ATGTTTCCCACCTGACCTG (199bp) \\
\hline Cx31 & TGAAAGAAAGGAGATGGG & GCTITAAGGAAACGGAC (364bp) \\
\hline Cx31.1 & CAAAGAATGACCCAAACTG & GACACCTTGAATCTGTAAACC (489bp) \\
\hline Cx32 & TССАТСАААССТТСССТС & ТТСТСТСТССАТААСТСССТС (391bp) \\
\hline $\mathrm{rC} \times 33$ & АААССАТСТТСАТССТСТТС & GCTITTCTGTCTACCTAAAACC (386bp) \\
\hline Cx36 & GAGCAAACGAGAAGATAAGAAG & CCGCTTCTACATCATCCA (195bp) \\
\hline Cx37 & GGCTGGACCATGGAGCCGGT & TTTCGGCCACCCTGGGGAGC (421bp) \\
\hline $\mathrm{Cx} 40$ & TाTGGCAAGTCACGGCAGGG & TTGTCACTGTGGTAGCCCTGAGG (311bp) \\
\hline $\mathrm{Cx} 43$ & TACCACGCCACCACTGGC & AATCTCCAGGTCATCAGG (407bp) \\
\hline Cx45 & AAAGAGCAGAGCCAACCAAA & GTCCCAAACCCTAAGTGAAGC (313bp) \\
\hline rCx46 & GGAAAGGCCACAGGGTTTCCTGG & GGGTCCAGGAGGACCAACGG (331bp) \\
\hline Cx50 & GGAAGGAGGATGAGAAAG & GAGAATGGAGGAGGAAAG (462bp) \\
\hline
\end{tabular}

\section{Differences among connexin isoforms in mouse, rat and humans}

Connexin sequences are found to be more conserved when comparing one isoform in different species (e.g., human and mouse $\mathrm{Cx} 43$ differ by only $12 \%$ at the nucleotide level and $2.5 \%$ at the amino acid level) than when comparing different isoforms in the same species (e.g., mouse $\mathrm{Cx} 40$ and $\mathrm{Cx} 43$ differ by $40 \%$ at the nucleotide level). Thus, the unique sites for endonucleases and the restriction fragment lengths might be conserved from mice to humans. However, evolutionary rates vary for different connexin genes among species (1). In rodents, the most striking difference that we have observed is related to rat/mouse $\mathrm{Cx} 30.3$ (Table 1). In humans, several connexins have also been cloned; their GenBank access numbers and predicted cleavage patterns are provided in Table 2. Note that Cx26 and Cx37 express endonuclease sites (and lengths of products) similar to those present in rat/mouse Cx26 and mouse Cx37, respectively.

\section{Conclusions}

In summary, the RT-PCR assay followed by connexin-specific endonucleases is simple, sensitive and reliable. Although initially developed for detection of small amounts of cDNA, we have found the method to be highly effective when preceding routine Northern blot analysis, enabling rapid discrimination of connexins belonging to group I from those belonging to group II in both large and small amounts of samples. In addition, the present methodology could be adapted to other gene families with high sequence conservation.

\section{Acknowledgments}

We thank Ms. M. Kremer for her technical expertise, Mrs Camilla Heinzmann (Qiagen Inc.) for technical support and Drs. R. Dermietzel and X. Zheng for their helpful comments. 


\section{References}

1. Bennett $M V L$, Zheng $X \&$ Sogin $M L$ (1995). The connexin family tree. In: Kanno Y, Kataoka K, Shiba Y, Shibata Y \& Shimazu T (Editors), Intercellular Communication Through GapJ unctions. Progress in Cell Research. Elsevier Science, B.V., The Netherlands, 3-8.

2. Condorelli DF, Parenti R, Spinella F, Salinaro AT, Belluardo N, Cardile V \& Cicirata $F$ (1998). Cloning of a new gap junction gene ( $\mathrm{C} \times 36)$ highly expressed in mammalian brain neurons. European J ournal of Neuroscience, 10: 1202-1208.

3. Sohl G, Degen J , Teubner B \& Willecke K (1998). The murine gap junction gene connexin36 is highly expressed in mouse retina and regulated during brain development. FEBS Letters, 428: 27-31.

4. Haefliger J A, Bruzzone R, J enkins N, Gilbert DJ , Copeland NG \& Paul DL (1992). Four novel members of the connexin family of gap junction proteins. Molecular cloning, expression and chromosome mapping. J ournal of Biological Chemistry, 267: 2057-2064.

5. Chomczynski P \& Sacchi N (1987). Singlestep method of RNA isolation by acid guanidinium thiocyanate-phenol-chloroform extraction. Analytical Biochemistry, 162: 156-159.

6. Saiki RK, Gelfand DH, Stoffel S, Scharf SJ , Higuchi R, Horn GT, Mullis KB \& Erlich HA (1988). Primer-directed enzymatic amplification of DNA with a thermostable polymerase. Science, 239: 487-491.

7. Mehler MF, Rozental R, Dougherty $M$, Spray DC \& Kessler J A (1993). Cytokine regulation of neuronal differentiation of hippocampal progenitor cells. Nature, 362: 62-65.

8. Rozental R, Mehler MF, Morales M Andrade-Rozental AF, Kessler J A \& Spray DC (1995). Differentiation of hippocampal progenitor cells in vitro: Temporal expression of intercellular communication coupling and voltage- and ligand-gated responses. Developmental Biology, 167: 350-362.

9. Carter TD, Chen XY, Carlile G, Kalapothakis E, Ogden D \& Evans WH (1996). Porcine aortic endothelial gap junctions: identification and permeation by caged InsP3. J ournal of Cell Science, 109: 1765-1773.

10. Chandross KJ, Spray DC \& Kessler J A (1996). Regulation of connexin expression in Schwann cells. In: Spray DC \& Dermietzel R (Editors), Gap J unctions in the Nervous System. Landes Bioscience Publishers, Austin, TX, 229-241.
11. Davies TC, Barr KJ , J ones DH, Zhu D \& Kidder GM (1996). Multiple members of the connexin gene family participate in preimplantation development of the mouse. Developmental Genetics, 18: 234243.

12. Dermietzel $R$, Farooq $M$, Kessler J A, Althaus $\mathrm{H}$, Hertzberg EL \& Spray DC (1997). Oligodendrocytes express gap junction proteins connexin32 and Cx45. Glia, 20: 101-114.

13. Hellmann $P$, Winterhager $E \&$ Spray DC (1996). Properties of connexin 40 gap junction channels endogenously expressed and exogenously overexpressed in human choriocarcinoma cell lines. Pflügers Archiv, 432: 501-509.

14. Oyamada $\mathrm{Y}$, Komatsu K, Kimura H, Mori M \& Oyamada M (1996). Differential regulation of gap junction protein (connexin) genes during cardiomyocytic differentiation of mouse embryonic stem cells in vitro. Experimental Cell Research, 229: 318-326.

15. Pozzi A, Risek B, Kiang DT, Gilula NB \& Kumar NM (1995). Analysis of multiple gap junction gene products in the rodent and human mammary gland. Experimental Cell Research, 220: 212-219.

16. Valdimarsson G, De Sousa PA \& Kidder GM (1993). Coexpression of gap junction proteins in the cumulus-oocyte complex. Molecular Reproduction and Development, 36: 7-15.

17. Rozental $R$, Morales $M$, Mehler MF, Urban $M$, Kremer M, Dermietzel R, Kessler J A \& Spray DC (1998). Changes in the properties of gap junctions during neuronal differentiation of hippocampal progenitor cells. J ournal of Neuroscience, 18: 1753-1762.

18. Zhang JT \& Nicholson BJ (1989). Sequence and tissue distribution of a second protein of hepatic gap junctions, Cx26, as deduced from its CDNA. J ournal of Cell Biology, 109: 3391-3401.

19. Willecke K, Kozjek G, Dahl E, Nicholson BJ \& Hennemann H (1992). Molecular cloning of mouse connexin26 and -32 : Similar genomic organization but distinct promoter sequence of two gap junction genes. European J ournal of Cell Biology, 58: 81-89.

20. Dahl E, Manthey D, Chen Y, Schwarz HJ , Chang YS, Lalley PA, Nicholson BJ \& Willecke K (1996). Molecular cloning and functional expression of mouse connexin30 , a gap junction gene highly expressed in adult brain and skin. J ournal of Biologi- cal Chemistry, 271: 17903-17910.

21. Tucker MA \& Barajas L (1994). Rat connexins 30.3 and 31 are expressed in the kidney. Experimental Cell Research, 213: 224-230.

22. Hennemann H, Dahl E, White J B, Schwarz HJ , Lalley PA, Chang S, Nicholson BJ \& Willecke K (1992). Two gap junction genes, connexin 31.1 and 30.3 , are closely linked on mouse chromosome 4 and preferentially expressed in skin. J ournal of Biological Chemistry, 267: 17225-17233.

23. Hoh J H, J ohn SA \& Revel J P (1991). Molecular cloning and characterization of a new member of the gap junction gene family, connexin31. J ournal of Biological Chemistry, 266: 6524-6531.

24. Hennemann $\mathrm{H}$, Schwarz HJ \& Willecke $\mathrm{K}$ (1992). Characterization of gap junction genes expressed in F9 embryonic carcinoma cells: molecular cloning of mouse connexin31 and -45 cDNAs. European J ournal of Cell Biology, 57: 51-58.

25. Paul DL (1986). Molecular cloning of cDNA for rat liver gap junction protein. J ournal of Cell Biology, 103: 123-134.

26. Willecke K, Heynkens R, Dahl E, Stutenkemper $\mathrm{R}$, Hennemann $\mathrm{H}$, J ungbluth S, SuchynaT \& Nicholson BJ (1991). Mouse connexin37: cloning and functional expression of a gap junction gene highly expressed in lung. J oumal of Cell Biology, 14: 1049-1057.

27. Hennemann H, Suchyna T, LichtenbergFrate $\mathrm{H}$, J ungbluth $\mathrm{S}$, Dahl $\mathrm{E}$, Schwarz J, Nicholson BJ \& Willecke K (1992). Molecular cloning and functional expression of mouse connexin 40 , a second gap junction gene preferentially expressed in lung. J ournal of Cell Biology, 117: 1299-1310.

28. Beyer EC, Paul DL \& Goodenough DA (1987). Connexin43: A protein from rat heart homologous to a gap junction protein from liver. J ournal of Cell Biology, 105: 2621-2629.

29. Ruangvoravat CP \& Lo CW (1992). Connexin 43 expression in the mouse embryo: localization of transcripts within developmentally significant domains. Developmental Dynamics, 194: 261-281.

30. Paul DL, Ebihara L, Takemoto LJ, Swenson KI \& Goodenough DA (1992). Connexin46, a novel lens gap junction protein, induces voltage gated current in nonjunctional plasma membrane of Xenopus oocytes. Journal of Cell Biology, 115: 1077-1089.

31. White TW, Bruzzone R, Goodenough DA \& Paul DL (1992). Mouse connexin50, a 
functional member of the connexin family of gap junction proteins, is the lens fiber protein MP70. Molecular Biology of the Cell, 3: 711-720.

32. Lee SW, Tomasetto C, Paul D, Keyimarsi K \& Sager R (1992). Transcriptional down regulation of gap-junction proteins blocks junctional communication in human mammary tumor cell lines. J ournal of Cell Biology, 118: 1213-1221.

33. Kumar NM \& Gilula NB (1986). Cloning and characterization of human and rat liver cDNAs coding for a gap junction protein. J ournal of Cell Biology, 103: 767-776.

34. Reed KE, Westphale EM, Larson DM, Wang $\mathrm{H}-\mathrm{Z}$, Veenstra RD \& Beyer EC (1993). Molecular cloning and functional expression of human connexin37, an endothelial cell gap junction protein. J ournal of Clinical Investigation, 91: 997-1004.

35. Kanter HL, Saffitz J E \& Beyer EC (1994). Molecular cloning of two human cardiac gap junction proteins, connexin40 and connexin45. J oumal of Molecular Cell Cardiology, 26: 861-868.

36. Fishman GI, Eddy RL, Shows TB, Rosenthal L \& Leinwand LA (1991). The human connexin gene family of gap junction proteins: Distinct chromosomal locations but similar structures. Genomics, 10: 250-256. 